\title{
Effects of Rubber Flooring on Feeding and Resting Behavior of Dairy Buffalo and Cows
}

\author{
Eyüp Eren GÜLTEPE*1, İbrahim Sadi ÇETINNGÜL1, İsmail BAYRAM¹, E. Hesna KANDIR², Beytullah \\ KENAR $^{3}$, Tuba BÜLBÜL ${ }^{1}$, Cangir UYARLAR ${ }^{1}$, Ümit ÖZÇINAR ${ }^{1}$ \\ ${ }^{1}$ Afyon Kocatepe University, Faculty of Veterinary Medicine, Department of Animal Nutrition and Nutritional Diseases, 03200, \\ Afyonkarahisar, Turkey \\ 2 Afyon Kocatepe University, Faculty of Veterinary Medicine, Department of Wildlife and Ecology, 03200, Afyonkarabisar, Turkey \\ 3 Afyon Kocatepe University, Faculty of Veterinary Medicine, Department of Microbiology, 03200, Afyonkarabisar, Turkey
}

\begin{abstract}
This experiment evaluated the effects of rubber laying surface on feeding and lying behavior kinetics of dairy buffaloes and cows. Fifty-four Anatolian dairy buffalo (Bubalus bubalis) and 18 Brown Swiss dairy cows were used in the experiment. The animals group-housed in pens with concrete floor before the rubber flooring. The behavior of the animals was recorded 24 hours for 15 days before and after rubber flooring with a video camera system in the barn. Behavior data were expressed as \% of observed animal in pen per hour for each species. Lying down behavior was assumed in a resting manner. The average number of buffaloes laying down increased after rubber flooring while there was no effect on resting behavior of the cows. The rubber flooring had no effect on feeding behavior of cows. Unexpectedly, the percent of buffaloes displaying feeding behavior decreased after rubber flooring. Results suggested that water buffalo may have different responses to management and housing strategies compared with the cows. However, further comparative studies with individual animal data and widespread behavioral observations may support a better understanding of behavioral response to modern intensive management strategies in dairy buffaloes.
\end{abstract}

Keywords: Lying behavior; bedding; cow comfort, loose-housing, water buffalo

\section{Sünger Altlık Uygulamasının Sütçü Mandalar ve İneklerde Beslenme ve Dinlenme Davranışları Üzerine Etkileri}

\section{ÖZ}

$\mathrm{Bu}$ çalışmada, sünger yataklık uygulamasının sütçü mandalar ve süt ineklerinde beslenme ile yatma davranışı üzerine etkileri değerlendirilmiştir. Çalışmada 44 baş sütçü Anadolu manda melezi (Bubalus bubalis) ve 18 baş İsviçre Esmeri süt ineği kullanılmıştır. Sünger altlık uygulamasından önce tüm hayvanlar beton zeminde grup halinde serbest biçimde barındırılmıştır. Hayvanların davranışları, sünger uygulamasının 15 gün önce ve sonrasında çiftlikte bulunan kapalı devre kamera sistemi ile 24 saat kaydedilmiştir. Davranış verileri, her bir hayvan türü için her bir padokta \% / saat olarak ifade edilmiştir. Tüm yatma davranış şekilleri, dinlenme davranısı olarak kabul edilmiştir. Sünger altlık uygulaması sonrasında; mandalarda yatan hayvan sayısında artış görülürken, ineklerde dinlenme davranışına altlık uygulamasının bir etkisi olmamışır. Beklenmedik şekilde, altık uygulamasının ardından beslenme davranışı gösteren ortalama manda sayısında düşüş görülmüştür. Elde edilen veriler, mandaların yönetim stratejileri ve barınma konusundaki değişikliklere ineklerden daha farklı tepkiler verebileceğini göstermiştir. Ancak bireysel hayvan verilerini içeren ve daha geniş çaplı davranış gözlemlerinin olduğu çalışmalar, sütçü mandaların modern entansif yönetim stratejilerine nasıl tepkiler oluşturabileceğinin anlaşılmasına yardımcı olabilir.

Anahtar Kelimeler: Yatma davranışı, altık, inek konforu, serbest sistem barındırma, manda

To cite this article: Gültepe E.E. Cetingül I.S. Bayram I. Kandır E.H. Kenar B. Bülbül T. Uyarlar C. Özz̧nar Ü. Effects of Rubber Flooring on Feeding and Resting Behavior of Dairy Buffalo and Cows. Kocatepe Vet J. (2019) 12(4):378-383.

Submission: 27.06.2019 Accepted: 17.09.2019 Published Online: 09.10.2019

ORCID ID; EEG: 0000-0002-2404-1232, İSÇ: 0000-0002-7608-6176, İB: 0000-0002-9993-7092,

BK: 0000-0001-6573-680X, CU: 0000-0002-7803-2454, ÜÖ: 0000-0002-1143-1215

*Corresponding author e-mail: eegultepe@gmail.com 


\section{INTRODUCTION}

Resting behavior (lying down) is very important for dairy cow productivity and a dairy cow spend about half of the day in the resting position (Krohn and Munksgaard 1993). Blood flow in mammary gland increases during lying down position in dairy cows (Rulquin and Caudal 1992). Evidence suggests that poor management practices that cause uncomfortable resting behaviors decrease milk production, growth hormone production and increase risk of lameness (Munksgaard and Lovendahl 1993, Fisher et al. 2002). High production dairy cows tend to rest immediately after feeding behavior due to the unique nature of rumination (Jensen et al. 2005). Duration of resting behavior in dairy cows depends on many factors, such as age, fever and diseases, housing conditions, amount and type of flooring material, excessive herd density (Krohn and Munksgaard 1993). Haley et al. (2000) reported that dairy cows housed with rubber flooring laid down more than cows housed with concrete floor during the day. Eicher et al. (2013) reported higher production for cows on rubber floor than the cows on concrete floor. Furthermore, the authors reported long-term chronic inflammation indicators in the cows housed with concrete floor compared with those housed on rubber. The evidence of the latter study suggests that improved productivity with rubber flooring may be a result of alleviating chronic inflammation, which is common in dairy cows due to high production and excessive intensive nutrition.

The water buffalo (Bubalis bubalis) has become an important actor in the global dairy industry, second only to dairy cattle in the value of dairy products produced (Sindhu and Arora 2011). According to FAO (2019) big data, there was a $118 \%$ rise in production of whole buffalo milk while a $42 \%$ rise in cow milk production from 1994 to 2016. This major change indicates an increasing trend in buffalo milk and buffalo milk products. As a result of commercial interest, buffalo nutrition has shifted from extensive conditions with wide pasture areas and water sources which allow some species-specific natural behavior such as wallowing to intensive conditions which has specific challenges on comfort and welfare of buffaloes such as fewer space allowance than dairy cow standards (De Rosa et al. 2009). Tripaldi et al. (2004) observed that buffalo cows housed intensive conditions without grazing and wallowing opportunities had higher plasma cortisol levels than the buffalo cows housed outdoor yard with free access potholes. In free-stall barn conditions, De Rosa et al. (2009) reported higher milk production for buffaloes had an ample outdoor lot than the buffaloes had no outdoor access. Grasso et al. (1999) concluded that the productivity of buffaloes affects more deleterious than the cows in the same poor housing conditions. Although the abundant research data are available about the feeding behavior of dairy cows (Neave et al. 2018), research data is limited for feeding behavior of buffalo cows housed in intensive conditions.

Therefore, the objective of this study was to compare the effect of rubber flooring or concrete flooring on feeding and resting behavior of dairy buffaloes and cows. Our secondary objective was to provide comparative data about dairy buffaloes and dairy cows housed with intensive conditions in a similar environment.

\section{MATERIALS and METHODS}

\section{Animals and housing}

The experiment was conducted with 54 Anatolian dairy buffalo and 18 Brown Swiss dairy cows from November to December 2015 in Afyon Kocatepe University Animal Teaching \& Research Center (Afyonkarahisar, $\quad$ Turkey, $\quad 38^{\circ} 41^{\prime} 52.6^{\prime \prime} \mathrm{N}$ $\left.30^{\circ} 40^{\prime} 01.1 " \mathrm{E}\right)$. The barn was arranged as a 2 -row barn with drive-through feed lane. The animals group-housed in pens with concrete floor. Due to potential challenges for interspecies hierarchy, buffalo and cows did not keep in same pens. All pens had $22.5 \mathrm{~m}$ width and $21 \mathrm{~m}$ length. All pens had an outdoor stall with soil floor and had a higher bedding area than floor in the middle without stalls. The bedding area allowed head-to-head (face) bedding position for two cows at the same time with $5.6 \mathrm{~m}$ length. All pens had automatic manure scraper systems and swinging cow brush for grooming. All areas had a concrete floor except for bedding area and outdoor stalls. After pre-treatment recording, the bedding area was covered with a specific rubber bedding material $(3.7 \mathrm{~cm}$ thickness, ISBIR Ranchbed®, Isbir Sunger Co., Ankara, Turkey). During the study, the animals were milked twice daily, had ad libitum access to water, fed by standard operating protocol for the Afyon Kocatepe University Teaching and Research Unit, which is a lactation diet based on NRC (2001) requirements. The diets were provided one time a day at $0800 \mathrm{~h}$ as a total mixed ration (TMR).

\section{Behavior data recording}

The behavior of the animals was recorded 24 hours for 15 days before and after rubber flooring with a video camera system in the barn (IP Box Type 1 / 2.8" progressive scan, LG Electronics, Seoul, South Korea). Behavior data were expressed as a percent of animal fed or lying down in the stall per hour for each species. Lying down behavior was assumed in a resting manner. In the records, a cow did a 'headdown' position in feed bunk, it assumed feeding behavior. The animal numbers and time duration of records were assumed reliable according to Ito et al. (2009) who concluded that $3 \mathrm{~d}$ of continuous data from 30 head cow per commercial dairy farm can 
provide reliable data analysis of dairy cow behavior.

\section{Statistical analysis}

Data analysis was performed with MedCalc software (version 16.4.3, MedCalc Software bvba, Ostend, Belgium). Normal distribution of the data was checked by Kolmogorov-Smirnov normality test and some data were log-transformed. Independent sample t-test was used interspecies comparisons. Paired sample t-test was used to evaluating the treatment effect of each species. Significance level was assumed $\mathrm{P}<0.05$ for all data. Hourly averages of behavior data were provided as a descriptive purpose.

\section{All data were expressed as $\bar{X} \pm S E M$.}

\section{RESULTS and DISCUSSION}

Descriptive hourly feeding and resting behavior means are shown in Fig. 1 and Fig. 2. In the pretreatment period, the highest percentage of feeding behavior was observed at $14^{\text {th }}$ hour of the day in buffalo and at $10^{\text {th }}$ hour of the day in cows $(69.0 \% \mathrm{vs}$. $69.2 \%$ of total animal/pen, respectively). The lowest percentage of feeding behavior was recorded at $4^{\text {th }}$ hour of day in buffalo ( $1 \%$ of total animal/pen). No cow observed in feeding behavior between $4^{\text {th }}-6^{\text {th }}$ hours of day in cow ( $0 \%$ of total animal/pen). After rubber flooring, highest percentage of feeding behavior was observed at $11^{\text {th }}$ hour of the day in buffalo and cows $(51.3 \%$ vs. $70.0 \%$ of total animal/pen, respectively). No animal showed feeding behavior between $5^{\text {th }}$ and $7^{\text {th }}$ hours of day in cow $(0 \%$ of total animal/pen). However, lowest percentage of feeding behavior was observed at $4^{\text {th }}$ hour of day in buffalo $(0.34 \%$ of total animal/pen).

Before the rubber flooring, highest percentage of resting behavior was observed at $1^{\text {st }}$ hour of the day in buffalo and between $3^{\text {rd }}$ and $6^{\text {th }}$ hour of the day in cows $(39.0 \%$ vs. $70.7 \%$ of total animal $/ \mathrm{pen}$, respectively). No animal was observed in resting behavior between $9^{\text {th }}-15^{\text {th }}$ hours of day in buffalo and $10^{\text {th }}-17^{\text {th }}$ hours of day in cow $(0 \%$ of total animal/pen). After rubber flooring, highest percentage of resting behavior was observed at $5^{\text {th }}$ hour of the day in buffalo and the cows $(50.3 \% \mathrm{vs}$. $67.5 \%$ of total animal/pen, respectively). No animal was observed in resting behavior between $9^{\text {th }}-12^{\text {th }}$ hours of day in cow and $10^{\text {th }}-12^{\text {th }}$ hours of day in buffalo after rubber flooring $(0 \%$ of total animal/pen).

Odyuo et al. (1995) reported eating, ruminating, idling, walking and sleeping behavior data of dairy buffaloes and they concluded that resting behaviors in buffaloes mostly recorded from midnight to earlier morning in the day. These findings are in agreement with our resting behavior data. The resting behavior of buffaloes slightly prolonged until morning feed delivery time $(0800 \mathrm{~h})$ after rubber flooring. Furthermore, resting buffaloes was recorded around noon hours after rubber flooring although there was no resting buffalo record at noon before the rubbering. The average number of buffaloes laying down increased after rubber flooring $(\mathrm{P}=0.046)$ while there was no effect on resting behavior of the cows. Rushen et al. (2007), who concluded that dairy cows on rubber floor spend more time resting (lying) than the cows on concrete during the day. Inconsistency between results of Rushen et al. (2007) and our findings may be explained by housing conditions. Although Rushen et al. (2007) observed the cows in the tie-stall barn housing system, there were no cubicles or stall in our study. However, de Arcipreste et al. (2018) observed plasticity (changes in behavioral patterns in relation to the environment) and consistency (similar behavioral responses in different situations) of heifers with different cubicle availability in pen. The authors observed consistency in lying behaviors as a response again to different housing conditions. Our findings on cows are in agreement with results of de Arcipreste et al. (2018). Although there was no flooring effect on resting behavior of cows, increased daily means of percents of lying buffalo through the soft flooring suggest that buffaloes are able to use more behavioral plasticity in response to rubber flooring than the cows. Our hypothesis about the buffalo can be supported by findings Salzano et al. (2019), who reported that milk of buffaloes which has $5 \mathrm{~m}^{2}$ more space allowance per head in pens provided greater antioxidant activity than the milk of buffaloes which has less space per head in pens.

In our study, rubber flooring had no effect on feeding behavior of cows in agreement with observations of Fregonesi et al. (2004), who concluded that rubber flooring did not affect time spent eating in dairy cows although animals spent more time for standing on rubber without eating than concrete floors. However, Tucker et al. (2006) reported that softer flooring caused greater total eating time in dairy cows than concrete floor. Tucker et al. (2006) observed the behavior data individually while Fregonesi et al. (2004) observed group-housed cows which are similar to our large pens. The variety of results may be explained by different housing conditions among the studies. Tucker et al. (2006) concluded that the main treatment effects on behavioral records can be masked by specific challenges of group housing, such as social dominance or copying of behavior (imitation).

In our knowledge, this is the first report on the effects of rubber flooring in dairy buffaloes in loosehousing conditions. Although there is limited data available, some studies showed that buffaloes may have a different response to intensive conditions than the cow (Napolitano et al., 2013). Even little efforts in 
management strategies, such as a shower or extended access to roughage, can positively affect of buffalo production (Thomas et al., 2005). Unexpectedly, however, the percent of buffaloes displaying feeding behavior decreased after rubber flooring. As a limitation of the study, individual data of animal or spent time eating data was not available. Therefore, the more tendency of buffaloes for rubber flooring to standing, idling or lying down than concrete may be decreased percent of the animal near the feed bunk.

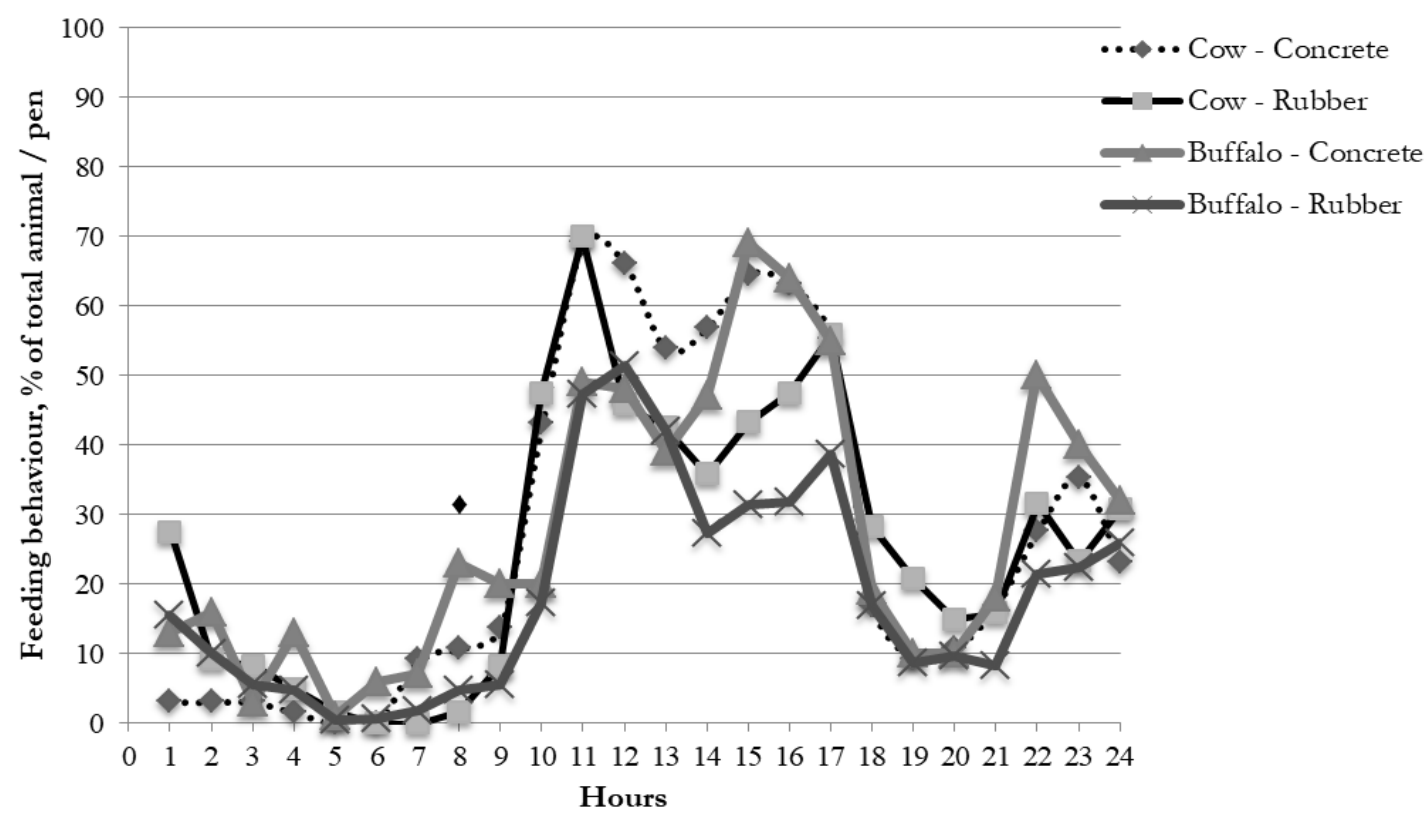

Fig. 1 Effect of rubber flooring on feeding behaviour of dairy buffalo and dairy cows. The mark ( indicates daily feed offering hour $(0800 \mathrm{~h})$.

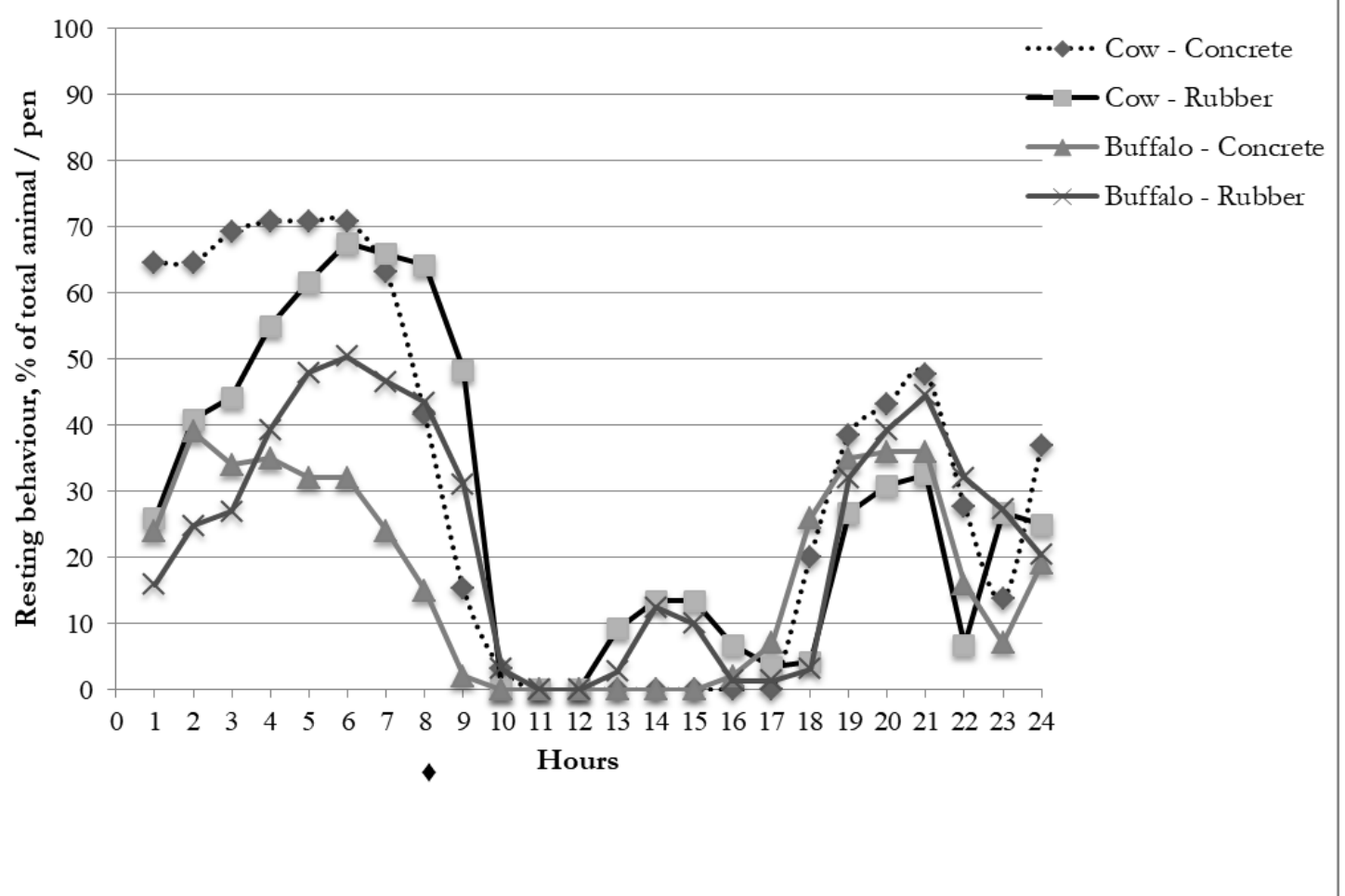

Fig. 2 Effect of rubber flooring on resting behaviour of dairy buffalo and dairy cows. The mark ( indicates daily feed offering hour $(0800 \mathrm{~h})$. 
Table 1. Effects of rubber flooring on feeding and resting behavior of dairy buffalo and cows (Means \pm SEM)

\begin{tabular}{lccccc}
\hline Item & Cow & SEM & Buffalo & SEM & P values \\
\hline Resting, \% & & & & & \\
\hline Pre-treatment & 31.73 & 5.76 & 17.54 & 3.06 & 0.004 \\
Post-treatment & 27.99 & 4.71 & 23.16 & 3.60 & 0.419 \\
P-values & 0.280 & 0.046 & \\
\hline
\end{tabular}

Feeding, \%

\begin{tabular}{lccccc}
\hline Pre-treatment & 27.37 & 5.06 & 28.00 & 4.15 & 0.349 \\
Post-treatment & 25.66 & 4.04 & 18.71 & 3.12 & 0.221 \\
& & & & & \\
P-values & 0.470 & 0.001 &
\end{tabular}

All values are expressed as \% of observed animal in pen per hour.

\section{CONCLUSIONS}

Results suggested that water buffalo may have different responses to management and housing strategies compared with the cows. However, further comparative studies with individual animal data and wide-spread behavioral observations (such as idling, active sleeping, ruminating, stepping and walking) may support a better understanding of behavioral response to modern intensive management strategies in dairy buffaloes.

\section{ACKNOWLEDGEMENT}

The authors thank the staff of Afyon Kocatepe University Animal Teacbing \& Research Center (Afyonkarabisar, Turkey) for their assistance with this study. The study was totally funded by Afyon Kocatepe University Scientific Research Projects Commission (Project No. 13.VF.ALTY.01). The results were partially presented in ICVAS 2016. Afyon Kocatepe University Animal Care and Use Committee decided that this study did not require the approval of the ethics committee (Case No.49533702/100).

\section{REFERENCES}

De Arcipreste, Mancera KF, Miguel-Pacheco GG, Galindo, F. Plasticity and consistency of lying and ruminating behaviors of heifers exposed to different cubicle availability: A glance at individuality. Appl Anim Behav Sci. 2018; 205:1-7. DOI: 10.1016/j.applanim.2018.05.020

De Rosa G, Grasso F, Braghieri A, Bilancione A, Di Francia A, Napolitano F. Behavior and milk production of buffalo cows as affected by housing system. J Dairy Sci. 2009; 92(3):907-912. DOI: 10.3168/jds.2008-1157

Eicher SD, Lay DC Jr, Arthington JD, Schutz MM. Effects of rubber flooring during the first 2 lactations on production, locomotion, hoof health, immune functions, and stress. J Dairy Sci. 2013; 96(6):3639-3651. DOI: $10.3168 /$ jds.2012-6049

FAO. Livestock and production database. http://www.fao.org/faostat/en/\#home; Access Date: 20.05.2019.

Fisher AD, Verkerk GA, Morrow CJ, Matthews LR. The effects of feed restriction and lying deprivation on pituitaryadrenal axis regulation in lactating cows. Livest Prod Sci. 2002; 73(2-3):255-263. DOI: 10.1016/S03016226(01)00246-9

Fregonesi JA, Tucker CB, Weary DM, Flower FC, Vittie T. Effect of rubber flooring in front of the feed bunk on the time budgets of dairy cattle. J Dairy Sci. 2004; 87(5):12031207. DOI: $10.3168 / j d s . S 0022-0302(04) 73270-1$

Grasso F, Napolitano F, de Rosa G, Quarantelli T, Serpe L, Bordi A. Effect of pen size on behavioral, endocrine, and immune responses of water buffalo (Bubalus bubalis) calves. J Anim Sci. 1999; 77(8):2039-2046. DOI: $10.2527 / 1999.7782039 x$

Haley DB, Rushen J, de Passille AM. Behavioural indicators of cow comfort: activity and resting behaviour of dairy cows in two types of housing. Can J Anim Sci. 2000; 80(2):257-263. DOI: 10.4141/A99-084

Ito K, Weary DM, von Keyserlingk MA. Lying behavior: Assessing within- and between-herd variation in freestall-housed dairy cows. J Dairy Sci. 2009; 92:4412-4420. DOI: $10.3168 /$ jds.2009-2235

Jensen MB, Pedersen LJ, Munksgaard L. The effect of reward duration on demand functions of rest in dairy heifers and lying requirements as measured by demand functions. Appl Anim Behav Sci. 2005; 90(3-4):207-217. DOI: 10.1016/j.applanim.2004.08.006

Krohn CC, Munksgaard L. Behaviour of dairy cows kept in extensive (loose housing/pasture) or intensive (tie-stall) environments. II. Lying and lying-down behaviour. Appl Anim Behav Sci. 1993; 37(1): 1-6. DOI: 10.1016/01681591(93)90066-X

Munksgaard L, Lovendahl P. Effects of social and physical stressors on growth hormone levels in dairy cows. Can J Anim Sci. 1993; 73(4):847-853. DOI: 10.4141/cjas93-087 
Napolitano F, Pacelli C, Grasso F, Braghieri A, de Rosa G. The behaviour and welfare of buffaloes (Bubalus bubalis) in modern dairy enterprises. Animal. 2013; 7:1704-1713. DOI: $10.1017 /$ S1751731113001109

Neave HW, Weary DM, von Keyserlingk MAG. Review: Individual variability in feeding behaviour of domesticated ruminants. Animal. 2018; 12:s419-s430. DOI: $10.1017 / \mathrm{S} 1751731118001325$

NRC. Nutrient Requirements of Dairy Cattle. $7^{\text {th }}$ rev. ed., The National Academic Press, Washington DC, USA. 2001.

Odyuo LT, Jana DN, Das N. Maintenance behaviour of Murrah buffalo under an intensive management system. Appl Anim Behav Sci. 1995; 45:293-299. DOI: 10.1016/0168-1591(95)00573-B

Rulquin H, Caudal JP. Effects of lying or standing on mammary blood flow and heart rate in dairy cows. Ann Zootech. 1992; 41(1):101.

Rushen J, Haley D, De Passille AM. Effect of softer flooring in tie stalls on resting behavior and leg injuries of lactating cows. J Dairy Sci. 2007; 90:3647-3651. DOI: $10.3168 /$ jds.2006-463

Salzano A, Licitra F, D’Onofrio N, Balestrieri ML, Limone A, Campanile G, D'Occhio MJ, Neglia G. Space allocation in intensive Mediterranean buffalo production influences the profile of functional biomolecules in milk and dairy products. J Dairy Sci. 2019; In Press. DOI: 10.1016/0168-1591(95)00573-B.

Sindhu JS, Arora S. Buffalo Milk, In: Encyclopedia of Dairy Sciences, Ed; Fuquay JW, 2nd Ed., Elsevier Academic Press, MA, USA. 2011; pp. 503-511.

Thomas CS, Nordstrom J, Svennersten-Sjaunja K, Wiktorsson $\mathbf{H}$. Maintenance and milking behaviours of Murrah buffaloes during two feeding regimes. Appl Anim Behav Sci. 2005; 91:261-276. DOI: 10.1016/j.applanim.2004.11.002

Tripaldi C, De Rosa G, Grasso F, Terzano GM, Napolitano F. Housing system and welfare of buffalo (Bubalus bubalis) cows. Anim Sci. 2004; 78(3):477-483. DOI: 10.1017/S1357729800058872

Tucker CB, Weary DM, de Pasille AM, Campbell B, Rushen J. Flooring in front of the feed bunk affects feeding behavior and use of freestalls by dairy cows. J Dairy Sci. 2006; 89: 2065-2071. DOI: 10.3168/jds.S0022$0302(06) 72274-3$ 